\title{
Effects of Plant Diversity and Time of Colonization on an Herbivore-Plant Interaction
}

\author{
Catherine E. Bach \\ Division of Biological Sciences, University of Michigan, Ann Arbor, Michigan 48109, USA
}

Summary. Experimental field plantings showed that plant diversity strongly affected the population dynamies of a specialist herbivore, the striped cucumber beetle, Acalymma vittata (Fab.) (Coleoptera: Chrysomelidae). Population densities over time were characterized by two peaks in numbers (from colonization and reproduction, respectively) and were consistently higher in cucumber monocultures (Cucumis sativus L.) than in polycultures of cucumbers, corn (Zea mays L.), and broccoli (Brassica oleracea L.). Greater abundances in monocultures appear to result from two factors: (1) per individual reproductive rates were greater in monocultures than in polycultures, and (2) mark-recapture studies confirmed that beetles stay in monocultures for a longer period of time than in polycultures. Differences in predation did not appear to contribute to the overall differences in herbivore abundances.

The primary impact of $A$. vittata on its host plant, $C$. sativus, is the dissemination of bacterial wilt disease, Erwinia tracheiphila (E.F.Sm.). Greater numbers of beetles led to greater plant mortality in monocultures. It is suggested that factors other than numbers of beetles (e.g., shading, allelopathy, microclimate) are more important in influencing plant reproduction, since cucumber plants in monocultures had greater yields than did plants grown in polycultures. However, time of beetle colonization strongly affected plant parameters, indicating that the length of time during which herbivores are interacting with plants is of critical importance to plant survivorship, and thus reproduction.

\section{Introduction}

Plant diversity has long been known to affect both the diversity (Murdoch et al., 1972; Root, 1973; Price and Waldbauer, 1975) and stability (Pimentel, 1961 b, 1977; Southwood and Way, 1970; van Emden and Williams, 1974) of the hervibore community. For many agricultural ecosystems, specialist herbivores often comprise the major portion of the herbivore load and function as "organizer" species among the herbivores of a particular host plant (Root, 1973). Thus, the population dynamics of the major specialist herbivore on a plant species often are important determinants of total herbivore load. Studies comparing abundances of specialist herbivores in simple and diverse communities have documented that monocultures of host plants have greater numbers of herbivores than do more diverse habitats (Pimentel, $1961 \mathrm{~b}$; Tahvanainen and Root, 1972; Root, 1973; Dempster and Coaker, 1974; Smith, 1976a; Altieri et al., 1977, 1978). However, few studies have examined the dynamics of the interaction between the herbivores and their host plants (i.e., what is the impact of greater numbers of specialist herbivores upon plants in monocultures?).

Two basic hypotheses have been proposed to explain higher insect densities in simple as compared to diverse plant communities (Root, 1973). The "resource concentration" hypothesis predicts lower herbivore abundances in diverse communities because specialist herbivores in diverse communities will: (1) be less likely to find their host plant because of confusing chemical and/or visual stimuli, (2) tend to stay for a shorter period of time simply because the probability of landing on a non-host plant is increased, and (3) have lower survivorship and fecundity. The "enemies" hypothesis attributes lower herbivore densities in diverse habitats to a higher density of predators and parasitoids. Higher populations of predators and parasitoids should be maintained in diverse communities because they can exploit the greater diversity of herbivores which become available at different times or in different microhabitats (Flaherty, 1969) and the greater diversity of special resources, such as nectar and pollen (Price and Waldbauer, 1975). Several studies support various aspects of these hypotheses (for a review, see Cromartie, 1979), but few studies have tested both hypotheses for the same herbivore-plant interaction.

In this study, I investigated the following questions: (1) Are population densities of a specialist herbivore species greater in monocultures of host plants than in polycultures containing additional plant species?, (2) If so, do differences in reproductive rates, movement patterns, and/or predation account for the observed differences in herbivore abundances?, and (3) How does plant diversity influence the dynamics of the interaction between a specialist herbivore and its host plant, with particular reference to plant yield and survivorship?

I studied the interaction between an agricultural pest species, the striped cucumber beetle, Acalymma vittata (Fab.) (Coleoptera: Chrysomelidae) and its host plant, the cucumber, Cucumis sativus L. (Family Cucurbitaceae). Acalymma vittata is a specialist on plants in the Family Cucurbitaceae; larvae develop only on the roots of cucurbits, whereas adults have a strong preference for foliage, stems, and flowers of cucurbits (Houser and Balduf, 1925). One generation per year occurs in Michigan, with egg laying by over-wintered adults occurring in June and July and new generation adults emerging in August and September. Individuals of A. vittata cause damage to cucurbits in three ways: vegetation consumption, root destruction, and disease dissemination. Of these, transmission of bacterial wilt disease [Erwinia tracheiphila (E. F. Sm.)] appears to be the most serious, since plants experience rapid wilting and death (Smith, 1911). 


\section{Materials and Methods}

Six experimental plots were established during the summer of 1976 near Whitmore Lake, Michigan, in an old field which had been fallow for eight years. Each plot was $7 \mathrm{~m}$ by $7 \mathrm{~m}$ and was separated from the nearest plot by $21 \mathrm{~m}$ of old field vegetation. The six plots were arranged linearly, $35 \mathrm{~m}$ from a nearby hedgerow. The hedgerow and intervening old field could provide nesting sites and alternate food for predators and parasitoids.

The composition of the six plots was: two corn (Zea mays, variety Golden Bantem) monocultures, two cucumber (Cucumis sativus, variety Tablegreen) monocultures, and two polycultures of corn, cucumbers, and broccoli (Brassica oleracea, variety Italian Green Sprouting). The positions of the plots were determined using a random numbers table. The two corn monocultures (plots 2 and 6) each contained 36 plants (6 rows of 6 plants each) and the two cucumber monocultures (plots 3 and 5) each contained 81 plants in 9 rows. The two polycultures (plots 1 and 4) each contained 84 cucumber plants (in 7 rows of 12 plants each), 36 corn plants (in 3 rows of 12 each), and 36 broccoli plants (in 3 rows of 12 each). The rows in the polycultures were arranged: cucumber, corn, cucumber, broccoli, cucumber, etc.

Because both cucumbers and corn are eaten by $A$. vittata (even though cucumbers are the preferred food), it was necessary to create both monocultures and polycultures with cucumbers and corn. Broccoli was included in the polycultures because it is known to support a large herbivore fauna (Root, 1973) and it increased both taxonomic and height diversity. Densities of the cucumber monocultures represent a balance between the need for an adequate number of plants to sample and the need to minimize intense plant competition which might mask the effects of herbivores on the plants. In order to maintain a constant density of cucumbers and corn between monocultures and polycultures (so that observed differences in herbivory would not just be a reflection of different densities of host plants), the polycultures had a greater total plant density. Thus, it was necessary to have a low plant density in the corn monocultures to minimize the difference in total density between monocultures and polycultures.

Seeds were planted on 9 May, 1976, after the last frost. Where seeds failed to germinate, young plants from another garden were transplanted. To control weeds, sheets of black plastic were placed between the rows and mulch of grass clippings between the plants within the rows.

The abundances of Acalymma vittata on cucumbers and corn in the experimental plots were determined throughout the summer by direct observation. On eighteen sampling days [between 6 July and 19 September, corresponding to between 58 and 133 days after planting (DAP)], numbers of $A$. vittata were recorded. Each cucumber plant was carefully examined for beetles in flowers, on stems, and on or under leaves. Numbers of $A$. vittata on corn were sampled on five days between 20 July and 2 September, by searching for beetles on leaves, silk, and inside leaf whorls. This method censused the entire population and rarely disturbed the beetles or caused them to fly away, except towards the end of the season when there were large numbers of beetles per plant.

Herbivore movements were studied by a mark-recapture method. During the month of August, individuals of $A$. vittata were marked with Testors paint with a different color for each plot. Beetles were collected in the plots, marked, and then released by placing an open plastic bag containing the beetles in the center of the plot. On 7 August, 183 individuals were marked in cucumber monocultures and 50 individuals were marked in polycultures. In addition, later markings were done for certain plots: 752 marked in a monoculture on 18 August, 281 marked in a polyculture on 23 August, and 25 marked in a monoculture on 25 August. All cucumber plants were searched for beetles every three days until the end of the season.

Predators in the Order Hemiptera (Family Pentatomidae) were also sampled in the plots. Pentatomid bugs have been reported to be potentially important predators on $A$. vittata (Houser and Balduf, 1925) and were the most conspicuous and abundant predators in the plots. The number of pentatomids (primarily Euschistus spp.) on each plant was recorded on 13 days for cucumber plants (between 3 August and 23 September) and 4 days for corn plants (between 30 July and 2 September).

Cucumber plant survivorship and yield were measured weekly throughout the season to document the impact of herbivory on cucumber plants. Because the number of herbivores on corn plants was so low, herbivory effects on corn plants were not quantified. Since the principal damage to cucumber plants is the transmission of bacterial wilt disease, damage was assessed by counting the number of live cucumber plants in each plot on each herbivore sampling day (i.e., plants with at least one partially green leaf). Feeding damage to cucumber leaves appeared to be of minimal importance and hence was not quantified. Stem and root damage caused by larvae could not be determined without the destruction of plants, and thus were not measured.

Cucumber plant yield (a measure of relative reproductive output) was determined by weighing the cucumbers produced by each plant. On 15 days throughout the season between 11 July and 12 September, all cucumbers longer than approximately $15 \mathrm{~cm}$ were removed from each plant and the total weight per plant was recorded.

Comparisons of herbivore abundances and plant parameters in the two cucumber monocultures and two polycultures were carried out using a 2-way ANOVA on 81 plants per plot. Effects of plot diversity, replicate, and an interaction between diversity and replicate, on per plant abundances of $A$. vittata, plant survivorship, and plant yield, were determined. Means for all parameters were calculated for all cucumber plants, including non-surviving plants. Beetle abundance and yield data were transformed with a $\log$ transformation to statisfy the equality of variances assumption of ANOVA (tested with an F-test).

For those parameters measured or calculated on a total plot basis, such as reproductive rates and development time, comparisons were made using a 2-way ANOVA without replication, testing for effects of diversity and replicate. Per plot abundances of predators were compared with a Mann-Whitney $U$ test, since data from different sampling days was highly non-normal and unequal variances could not be stabilized with transformations. For similar reasons, Mann-Whitney $U$ tests were used to compare abundances of predators and herbivores on corn and cucumber plants.

\section{Results}

\section{Population Densities}

Acalymma vittata was more abundant over the entire season on cucumbers (total of 14,170 individuals on all cucumber plants) than on corn (total of 210 individuals on all corn plants) (Table 1). The majority of individuals found on corn (163) were found in one polyculture plot on one sampling day, 107 DAP. There were clearly greater numbers found on corn in polycultures than monocultures, since no individuals were found in corn monocultures. 
Table 1. Numbers of Acalymma vittata on corn and cucumbers in the six experimental plots. Means \pm standard deviations are presented for the number of beetles per plot per day for 5 and 18 sampling days, respectively. Per plant abundances were calculated by dividing the per plot abundances by the number of plants of the appropriate type in each plot

\begin{tabular}{|c|c|c|c|c|}
\hline \multirow[t]{2}{*}{ Plot diversity } & \multicolumn{2}{|l|}{ Per plot } & \multicolumn{2}{|c|}{ Per plant } \\
\hline & Corn & $\begin{array}{l}\text { Cucum- } \\
\text { bers }\end{array}$ & Corn & $\begin{array}{l}\text { Cucum- } \\
\text { bers }\end{array}$ \\
\hline $\begin{array}{l}\text { Corn monoculture } \\
\text { (plot 2) }\end{array}$ & $0.00 \pm 0.00$ & & 0.00 & \\
\hline $\begin{array}{l}\text { Corn monoculture } \\
\text { (plot 6) }\end{array}$ & $0.00 \pm 0.00$ & & 0.00 & \\
\hline $\begin{array}{l}\text { Cucumber mono- } \\
\text { culture (plot } 3 \text { ) }\end{array}$ & & $290.1 \pm 458.8$ & & 3.58 \\
\hline $\begin{array}{l}\text { Cucumber mono- } \\
\text { culture (plot } 5 \text { ) }\end{array}$ & & $306.8 \pm 836.0$ & & 3.79 \\
\hline $\begin{array}{l}\text { Polyculture } \\
\text { (plot 1) }\end{array}$ & $1.80 \pm 1.92$ & $86.6 \pm 113.4$ & 0.050 & 1.03 \\
\hline $\begin{array}{l}\text { Polyculture } \\
\text { (plot } 4 \text { ) }\end{array}$ & $40.20 \pm 68.96$ & $103.8 \pm 142.8$ & 1.12 & 1.24 \\
\hline
\end{tabular}

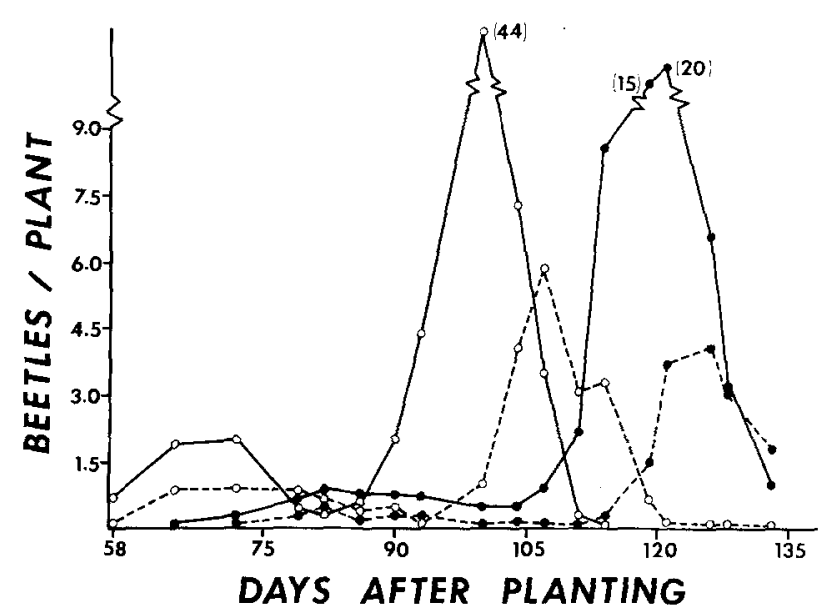

Fig. 1. Mean number of Acalymma vittata per cucumber plant over the entire season in cucumber monocultures (solid lines) and polycultures (dotted lines). Plots 1 and 3 are designated with closed circles and plots 4 and 5 with open circles

To compare beetle abundances on corn versus cucumber plants, the number of beetles per plant per sampling day was calculated (Table 1). For polycultures alone, numbers were greater on cucumbers than on corn (Mann-Whitney $U$ test, $W=-2.36$, $\mathrm{d} f=(10,36), p<0.01)$. Since no beetles were found in corn monocultures, numbers were clearly higher on cucumbers in monoculture than on corn in monoculture.

Population densities of $A$. vittata on cucumbers were characterized by two peaks, a small one early in the season (65-82 DAP) and a much larger one toward the end of the season (100-126 DAP) (Fig. 1). The initial peak was the result of colonization of the plots by adult beetles whereas the later peak in numbers was the result of reproduction within the plots. Because newly emerged beetles are much paler in color and have soft
Table 2. Total numbers of Acalymma vittata per cucumber plant over the entire season (means \pm standard deviations) in the experimental plots and associated F-values (1,320) from an ANOVA

\begin{tabular}{lc}
\hline Plot diversity & Total no. beetles \\
\hline Monoculture (plot 3) & $62.49 \pm 100.87$ \\
Monoculture (plot 5) & $67.70 \pm 130.87$ \\
Polyculture (plot 1) & $17.06 \pm 32.31$ \\
Polyculture (plot 4) & $23.15 \pm 37.32$ \\
\hline Effect & $F$ \\
\hline Diversity & $30.93 * *$ \\
Replicate & 0.019 \\
Interaction & 0.69 \\
\hline$* * p<0.01$ &
\end{tabular}

elytra for about two days, it was possible to distinguish between the parental generation beetles and those which emerged in the plots (offspring generation). By the time new beetles were beginning to emerge, most of the beetles of the previous generation had died. It is clear from looking at Fig. 1 that all plots were not colonized at the same time; in fact, plots 4 and 5 (one monoculture and one polyculture) had beetles as early as $58 \mathrm{DAP}$ and substantial numbers by $65 \mathrm{DAP}$, whereas beetles did not colonize plots 1 and 3 (one monoculture and one polyculture) in substantial numbers until 82 DAP. Thus, because replicate plots differed substantially in terms of time of beetle colonization, significant differences in beetle and plant parameters between replicate plots represent differences which are most probably caused by variance in time of beetle colonization.

To compare numbers of beetles on cucumbers, the total number of beetles per plant over the entire season was calculated (Table 2). Plant diversity strongly affected the number of beetles per plant $(p<0.01)$, but there was no effect of replicate or an interaction between diversity and replicate $(p>0.05$ for both). The number of beetles per plant was highly skewed (see Figure 2) since a majority of plants had few beetles and only a few plants had many beetles. More cucumber plants in polycultures $(25.6 \%$ as compared to $14.2 \%$ in monocultures) had fewer than two beetles over the entire season, and only $11.3 \%$ of the polyculture plants had greater than 64 beetles (as compared to $27.2 \%$ in monocultures).

These differences in numbers of beetles between monocultures and polycultures were significant not only for totals over the entire season, but also for individual sampling days (see Fig. 1). Numbers of beetles during the second peak in numbers caused by reproduction were clearly greater in monocultures than in polycultures (Table 3). Considering only those plants with beetles, there was a significant diversity effect on this estimate of the number of first generation beetles $(p<0.01)$. Replicate, or time of beetle colonization, even more strongly affected the peak number of first generation beetles; early colonized plots had greater peak numbers than did later colonized plots.

However, because the initial numbers of beetles colonizing the plots were not the same in all plots, a better measure of the rate of reproduction would be a reproductive rate per individual colonizing beetle (Table 3 ). This reproductive rate was greater in monocultures than in polycultures, but there was no effect of time of beetle colonization. Rates of development were not 


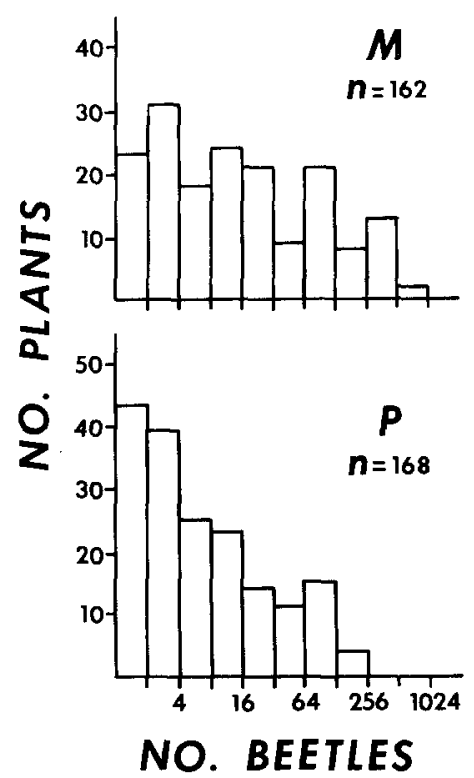

Fig. 2. Frequency of cucumber plants with various numbers of Acalymma vittata over the entire season in monocultures $(M)$ and polycultures $(P)$

affected by either plot diversity or time of colonization ( $p>0.05$ for both, Table 3). Thus, plot diversity seemed to affect the reproductive rates of individual beetles, but not development time.

\section{Movement Patterns}

Out of a total of 1,291 individuals marked, $148(11.5 \%)$ were later found, 140 in the same plot in which they had been marked (Table 4). A greater proportion of beetles was recaptured in the same monoculture in which they were originally marked, than in the same polyculture in which they were originally marked $\left(\chi^{2}=8.3, \mathrm{df}=1, p<0.05\right)$. This effect of plot diversity on the proportion of beetles found is apparent even after three days from the first marking $\left(\chi^{2}=5.4, \mathrm{df}=1, p<0.05\right)$, indicating that beetles tended to leave polycultures more rapidly than monocultures.

Only 8 out of $1,291(0.6 \%)$ beetles marked were found in a plot different from that in which they were marked. There was no difference between the proportion of beetles marked in monoculture or polyculture which were later found in a different plot $\left(\chi^{2}=0.34, \mathrm{~d} f=1, p>0.05\right)$. Even though 6 out of 8 went from a monoculture to a polyculture, there was no significant effect of plot type where beetles were marked on the type of plot where beetles were later found $\left(\chi^{2}=0.38, \mathrm{df}=1, p>0.05\right)$.

\section{Predation}

Numbers of pentatomid bugs on both corn and cucumber plants throughout the season were low (Table 5). Because there were no differences in numbers of pentatomids on corn between replicates ( $p>0.05$ for both), data were combined to make comparisons. A greater number of pentatomids were found on corn in polycultures than in monocultures $(\mathrm{W}=-2.74, \mathrm{df}=(8,8)$, $p<0.01)$. Because numbers of pentatomids on cucumbers were different between replicates ( $p<0.05$ for both), data for the replicates could not be combined. There were greater numbers of pentatomids on cucumbers in polycultures than monocultures for one comparison (plot 1 and plot $3 ; \mathrm{W}=-2.05, \mathrm{~d} f=(13,13), p<0.05$ ),
Table 3. Reproductive parameters of Acalymma vittata in the experimental plots and associated ANOVA results. Numbers of beetles at late peak (means \pm standard deviations) were calculated for those plants which had at least one beetle over the season $(N=16$ per plot, randomly chosen). Reproductive rate was calculated as the mean number of beetles per plant at late peak divided by the mean number of beetles at early peak. Rate of development represents the number of days between the date of late peak in beetle numbers and the date of early peak. Date of early peak was calculated as the mean of the two dates of highest initial numbers (since there were plateaus rather than peaks). Degrees of freedom for ANOVAs were $(1,60)$ for beetles at late peak and $(1,1)$ for reproductive rate and development time

\begin{tabular}{|c|c|c|c|}
\hline Plot diversity & $\begin{array}{l}\text { Beetles } \\
\text { at late peak }\end{array}$ & $\begin{array}{l}\text { Repro- } \\
\text { ductive } \\
\text { rate }\end{array}$ & $\begin{array}{l}\text { Rate of } \\
\text { develop- } \\
\text { ment }\end{array}$ \\
\hline Monoculture (plot 3) & $69.62 \pm 117.38$ & 23.53 & 37.0 \\
\hline Monoculture (plot 5) & $222.75 \pm 117.84$ & 22.00 & 31.5 \\
\hline Polyculture (plot 1) & $10.44 \pm 16.61$ & 8.85 & 45.5 \\
\hline Polyculture (plot 4) & $17.81 \pm 14.15$ & 6.60 & 38.5 \\
\hline Effect & $F$ & $F$ & $F$ \\
\hline Diversity & $8.76 * *$ & \multicolumn{2}{|c|}{$1,740.0 * 106.7$} \\
\hline Replicate & $25.97 * *$ & 27.5 & 69.4 \\
\hline Interaction & $5.82 *$ & & \\
\hline
\end{tabular}

Table 4. Data from mark-recapture study of $A$. vittata in the experimental plots. Numbers in parentheses represent percentage of total

\begin{tabular}{|c|c|c|c|c|c|}
\hline \multirow[t]{2}{*}{ Plot diversity } & \multicolumn{2}{|c|}{ First marking } & \multicolumn{3}{|c|}{ Entire season } \\
\hline & $\begin{array}{l}\text { No. } \\
\text { marked } \\
7 \text { August }\end{array}$ & $\begin{array}{l}\text { No. } \\
\text { found }^{\text {a }} \\
10 \text { August }\end{array}$ & $\begin{array}{l}\text { Total } \\
\text { no. } \\
\text { marked }\end{array}$ & $\begin{array}{l}\text { No. } \\
\text { found } \\
\text { in } \\
\text { same } \\
\text { plot }\end{array}$ & $\begin{array}{l}\text { No. } \\
\text { found } \\
\text { in dif- } \\
\text { ferent } \\
\text { plot }\end{array}$ \\
\hline $\begin{array}{l}\text { Monoculture } \\
\text { (plot 3) }\end{array}$ & 53 & $21(39.6)$ & 78 & $29(37.2)$ & $1(1.3)$ \\
\hline $\begin{array}{l}\text { Monoculture } \\
\text { (plot 5) }\end{array}$ & 130 & $31(23.8)$ & 882 & $90(10.2)$ & $6(6.7)$ \\
\hline $\begin{array}{l}\text { Polyculture } \\
\text { (plot } 1)\end{array}$ & 23 & $2(8.7)$ & 23 & $3(13.0)$ & 0 \\
\hline $\begin{array}{l}\text { Polyculture } \\
\text { (plot } 4 \text { ) }\end{array}$ & 27 & $3(11.1)$ & 308 & $18(5.8)$ & $1(0.3)$ \\
\hline
\end{tabular}

a In same plot

but no difference for the other comparison (plot 4 and plot 5; $\mathrm{W}=0.28, \mathrm{df}=(13,13), p>0.05)$. Numbers of pentatomids per plant were higher on corn than on cucumbers both for monocultures $(\bar{x}=0.031$ for corn, $\bar{x}=0.013$ for cucumbers; $\mathrm{W}=2.27, \mathrm{df}=(8,26)$, $p<0.05)$ and for polycultures $(\bar{x}=0.070$ for corn, $\bar{x}=0.030$ for cucumbers; $\mathrm{W}=3.49, \mathrm{df}=(8,26), p<0.01)$. 
Table 5. Abundances of pentatomid predators in the experimental plots. Numbers (means \pm standard deviations) are totals per plot per day for 4 sampling days for corn and 13 sampling days for cucumbers

\begin{tabular}{lll}
\hline Plot diversity & \multicolumn{2}{l}{ No. pentatomids } \\
\cline { 2 - 3 } & Corn & Cucumbers \\
\hline Corn monoculture (plot 2) & $1.00 \pm 1.15$ & \\
Corn monoculture (plot 6) & $1.25 \pm 0.50$ & \\
Cucumber monoculture (plot 3) & & $1.46 \pm 1.66$ \\
Cucumber monoculture (plot 5) & & $0.46 \pm 0.78$ \\
Polyculture (plot 1) & $5.25 \pm 3.40$ & $4.15 \pm 2.79$ \\
Polyculture (plot 4) & $5.00 \pm 3.56$ & $0.77 \pm 1.09$ \\
\hline
\end{tabular}

Table 6. Total weight of cucumbers produced per plant over the entire season (means \pm standard deviations) in the experimental plots and associated F-values (1,320) from an ANOVA

\begin{tabular}{llr}
\hline Plot diversity & $\begin{array}{l}\text { Date of } \\
\text { colonization }\end{array}$ & \multicolumn{1}{l}{$\begin{array}{l}\text { Total yield } \\
(\mathrm{g})\end{array}$} \\
\hline Monoculture (plot 3) & 82 DAP & $1,205.8 \pm 823.0$ \\
Monoculture (plot 5) & 65 DAP & $846.5 \pm 612.8$ \\
Polyculture (plot 1) & 82 DAP & $897.6 \pm 575.2$ \\
Polyculture (plot 4) & 65 DAP & $582.1 \pm 448.3$ \\
\hline
\end{tabular}

\begin{tabular}{lc}
\hline Effect & $F$ \\
\hline Diversity & $24.16^{* *}$ \\
Replicate & $20.32^{* *}$ \\
Interaction & 0.57 \\
\hline
\end{tabular}

** $\quad p<0.01$

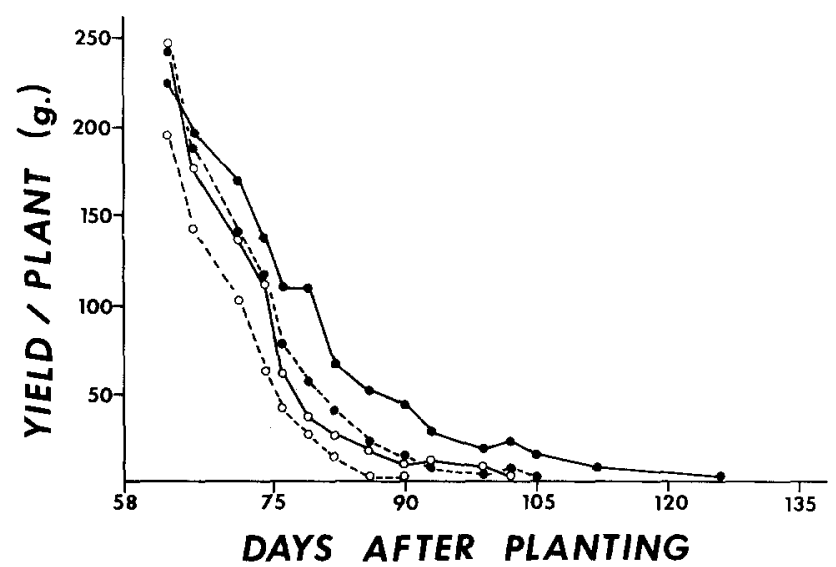

Fig. 3. Mean weight of cucumbers produced per plant over the entire season in monocultures (solid lines) and polycultures (dotted lines). Plots colonized early by beetles are designated with open circles (plots 4 and 5) and those colonized late with closed circles (plots 1 and 3)

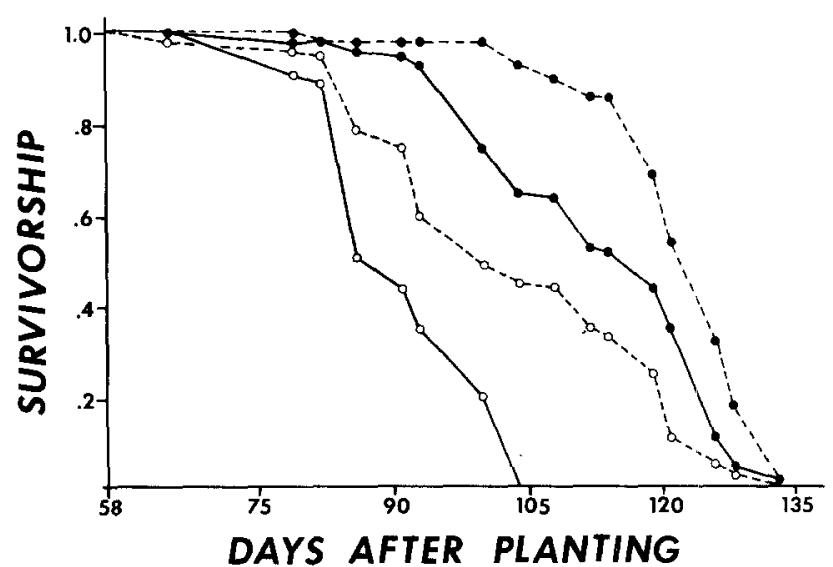

Fig. 4. Survivorship curves for cucumber plants in monocultures (solid lines) and polycultures (dotted lines). Survivorship is measured as the proportion of plants alive throughout the season. Plots colonized early by beetles are designated with open circles (plots 4 and 5) and those colonized late with closed circles (plots 1 and 3)

\section{Plant Yield}

Yield of the cucumber plants in terms of fruit weight decreased throughout the season (Fig. 3). This decrease was due primarily to fewer plants producing cucumbers as the season progressed, not to decreases per plant in the weight of cucumbers produced (since the mean yield was calculated for all plants, including those no longer alive). Total plot yields over the entire season were higher in the two plots which were colonized later (monoculture, $96.47 \mathrm{~kg}$; polyculture, $72.84 \mathrm{~kg}$ ) as compared to the two plots colonized early (monoculture, $67.71 \mathrm{~kg}$; polyculture, $46.87 \mathrm{~kg}$ ). Both plot diversity and time of colonization affected the total yield produced per individual plant ( $p<0.01$ for both, Table 6). Thus, cucumber plants in monocultures had higher yields than in polycultures. It can be seen from Fig. 3 that these differences between plots are clearly true not just for total yield, but also for individual sampling days. Plants in the late colonized monoculture consistently had higher yields than in all other plots, whereas plants in the early colonized polyculture had consistently lower yields.

\section{Plant Survivorship}

Survivorship of plants, measured by the average number of days alive after planting, also was affected both by diversity and time of colonization; the effect of time of colonization $(\mathrm{F}=214.00$, $\mathrm{df}=(1,320), p<0.001)$ was even stronger than the effect of plot diversity $(\mathrm{F}=20.40, \mathrm{df}=(1,320), p<0.01)$. Because the variances for this test were unequal $(\mathrm{F}=12.01, p=0.00)$ and could not be stabilized, the results of this test need to be interpreted with caution. However, survivorship curves for the four plots (Fig. 4) confirm the results of the ANOVA; clearly both diversity and time of colonization affect the rate of plant mortality.

Plants in those plots which were colonized early had lower survivorships than did those in plots colonized later, probably because of the bacterial wilt disease spread by beetles. This lower survivorship in turn directly affected plant yields. However, plants in monocultures had greater yields than plants in polycultures, even though there was lower survivorship in monocultures (because of greater numbers of beetles). For individual plants, there were significant positive correlations between the total number 
of beetles on the plant, longevity of the plant, and total yield (number of beetles-plant survivorship, $r=0.23, p<0.01$; number of beetles-yield, $r=0.35, p<0.01$; yield-plant survivorship, $r=0.31$, $p<0.01$ ). Obviously the longer a plant lives, the greater the weight of cucumbers and number of beetles it would be expected to have over the season.

\section{Discussion}

Population densities of $A$. vittata on its host plant were strongly affected by a small increase in plant species diversity, as evidenced by nearly an order of magnitude greater numbers in monocultures than in polycultures. These results agree with those from other studies comparing herbivore abundances in simple and diverse communities (Pimentel, $1961 \mathrm{~b}$; Tahvanainen and Root, 1972; Root, 1973; Dempster and Coaker, 1974; Smith, 1976a; Altieri et al., 1977, 1978). It appears that the presence of corn and broccoli confers an "associational resistance" to cucumbers, as reported for collards interplanted with tobacco and tomatoes (Tahvanainen and Root, 1972).

Of the two hypotheses proposed to explain such differences in herbivore abundances (Root, 1973), two aspects of the "resource concentration" hypothesis seem to be supported by this study, whereas there is no evidence supporting the "enemies" hypothesis. Differences in both reproductive rates and movement patterns are consistent with predictions from the "resource concentration" hypothesis that beetles will have higher reproductive rates and a longer tenure time in areas where their host plants are more concentrated. The greater per individual reproductive rates of A. vittata in monocultures than in polycultures (consistent with results reported by Altieri et al., 1977) partially explain the greater numbers of first generation beetles in monocultures, whereas longer tenure time in monocultures (as suggested by the mark-recapture study) appears to contribute to the greater population densities in monocultures over the entire season.

Differences in reproductive success and movement patterns in monocultures and polycultures may result from: (1) differences in microclimatic conditions, (2) interference caused by chemicals from non-host plants (Kennedy, 1965; Altieri et al., 1977), and/or (3) differences in host plant quality, since both absolute quality (chemistry and morphology) and relative quality (abundance and distance from other plants) (Atsatt and O'Dowd, 1976) would be different in monocultures and polycultures. Although Bach (1979) found that one aspect of host plant quality (plant survivorship) did not contribute to differences in herbivore abundances, it seems likely that biochemical quality strongly influenced the interaction between A. vittata and C. sativus. Cucurbitacins (secondary compounds contained in all plants in the Family Cucurbitaceae) act as feeding stimulants to cucumber beetles and positively affect the amount of feeding damage by beetles and thus the probability of leaving a plot (or just the probability of locomotion); in fact, flight patterns have been shown to be influenced by host plant odor (Douwes, 1968). In addition, beetles may have a longer tenure time in monocultures because they display different flight patterns after landing on a host versus a non-host plant or because of aggregation pheromones, one of which has been isolated for a closely related species, Diabrotica undecimpunctata howardi Barber (DaCosta and Jones, $1971 \mathrm{~b}$ ).

The highly skewed distribution of beetles on individual cucumber plants most likely also is a function of cucurbitacins. Initial feeding on one plant leads to greater cucurbitacin release (Howe et al., 1976) which then causes more beetles to congregate on that particular plant. It has also been suggested that non- random feeding on host plants may be mediated by aggregation pheromones (DaCosta and Jones, 1971 b; Howe et al., 1976). Whatever the cause, plants in monocultures not only had a greater herbivore impact in terms of number of beetles over the season, but also a greater chance of having any beetles at all, thus a greater chance of acquiring bacterial wilt disease.

The low numbers of pentatomid predators in all plots throughout the season suggest that predation on cucumber beetles, at least by these insects, is not an important influence on the abundance of herbivores. However, actual predation pressure may be better measured by a ratio of the number of predators to the number of herbivores, which would be much greater in polycultures. The fact that there were more pentatomids on corn in polycultures than monocultures (which is consistent with the "enemies" hypothesis) suggests the possibility that predation on corn herbivores may indeed be higher in polycultures. Even though there were significant differences in numbers of pentatomids on cucumbers in monocultures and polycultures (for one comparison), it seems highly unlikely that these low densities of predators could account for the large and consistent differences in abundances of $A$. vittata on cucumbers. These inconsistent results were not entirely unexpected, since other studies have reported both higher and lower abundances of predators in diverse communities as compared to simple communities (higher: Pimentel, 1961 a; Dempster, 1969; Smith, 1969, 1976b; Dempster and Coaker, 1974; lower: Pimentel, 1961 b; Pollard, 1971).

In addition to the two proposed hypotheses (" resource concentration" and "enemies"), there is another quite different possible explanation which was not controlled for in this study. The observed differences in herbivore abundances could simply be due to the different total plant densities in monocultures and polycultures, and not actually be affected by the presence of other plant species. Because the polycultures had twice the total plant density of the monocultures, cucumber plants there may have been subjected to greater plant competition, and thus may have been different in size or quality (even though the number of cucumber plants was the same) from the plants in monocultures. However, Bach (in prep.) controlled for both plant density and plant diversity and found that differences in host plant quantity (density, growth, and reproduction) did not contribute to greater beetle numbers in monocultures than in polycultures.

It is not surprising that beetles were more abundant on cucumbers than on corn, both in monocultures and polycultures, since $A$. vittata is a cucurbit specialist. What is interesting is that there were more beetles on corn in polycultures than on corn in monocultures (the opposite pattern to that for abundances on cucumbers). Since $A$. vittata only utilizes corn as an alternative source of pollen and not as a larval habitat, it seems likely that beetles on the preferred host (cucumbers) in polycultures might feed occassionally on corn in the same plot, but would not go to or remain in plots with no preferred hosts. While other studies have documented differences between herbivore species in their response to diversity (Cromartie, 1975; Root, 1975), this study points out different responses within one herbivore species.

In addition to effects of plot diversity on numbers of beetles, there is strong evidence that plot diversity also affects plant growth and reproduction. The greater yields of plants in monocultures than in polycultures colonized at the same time may be a result of increased plant competition in the polycultures (because of a greater total plant density and/or interspecific effects such as increased shading by corn, allelopathic chemicals in the soil, etc.). In addition, yields may be affected by other factors which differ between monocultures and polycultures, such as microclimate and 
principal mode of competition (light versus nutrient competition). It appears that the number of beetles on a plant was not an important influence on yields (as in Hill et al., 1948; Dempster, 1969). However, it is difficult even to speculate as to how much of the variance in yield is explained by differences in other plant parameters (such as plant size and numbers of flowers) which might be influenced by the number of beetles.

Even though beetles did not appear to detrimentally affect total plot yield, they did significantly increase plant mortality, thus affecting the yield of those plants which died. Since most plants developed symptoms of bacterial wilt disease (Erwinia tracheiphila) carried by the beetles, it seems likely that the plot diversity effect on survivorship is a direct result of different numbers of beetles. Greater numbers of beetles initially in monocultures would cause a greater incidence of bacterial wilt disease, which in turn would lead to greater numbers of beetles because of greater cucurbitacin release. Both Haynes and Jones (1975) and Smith (1911) found that $A$. vittata prefers to feed on leaves wilted by E. tracheiphila. In addition, beetle movements from plant to plant (and thus, disease spread) would be easier in monocultures, since there would be no interference from other plant species. However, it is also possible that enhanced survivorship in polycultures may result from decreased intraspecific competition, lower beetle reproductive rates, or beneficial effects from the other plant species.

This study points out the dramatic effect of time of beetle colonization on an herbivore-plant interaction, which has not been documented in other similar studies. Even though the total number of beetles was not influenced by how early in the season plants were colonized, the herbivore impact as measured by actual effects on cucumber plant yield and survivorship was strongly influenced by time of colonization. In fact, the time at which beetles colonized the plots even more strongly affected plant mortality than did plot diversity, as evidenced by the twenty-fold larger F-value. This may be partially due to a greater susceptibility of the cucumber plants to bacterial wilt disease earlier in the season or simply a greater length of time for plant-plant dissemination by beetles. Moreover, lower yields in early colonized plots probably resulted from the shorter lifespans of plants in early colonized plots.

In conclusion, these experiments substantiated the hypothesized differences in abundance of $A$. vittata in plots with different plant diversities. It is suggested that differences in movement patterns and rates of reproduction may account at least in part for the observed greater numbers of $A$. vittata in monocultures than in polycultures. Both numbers of herbivores and time of herbivore colonization were found to strongly affect plant survivorship, and thus indirectly affect plant yield.

Acknowledgements. This research was supported in part by a Horace H. Rackham School of Graduate Studies Predoctoral Fellowship and a Woman's National Farm and Garden Association Sarah Bradley Tyson Memorial Fellowship. I would like to thank Brian Hazlett for assistance with data collection and plot maintenance, and Diane De Steven, Brian Hazlett, Michael Huston, Deborah Rabinowitz, Beverly Rathcke, John Vandermeer, and John Witter, for critical comments on the manuscript. This research is part of a dissertation submitted to the University of Michigan in partial fulfillment of the requirements for the PhD degree.

\section{References}

Altieri, M.A., Francis, C.A., van Schoonhoven, A., Doll, J.D.: A review of insect prevalence in maize (Zea mays L.) and bean (Phaseolus vulgaris L.) polycultural systems. Field Crops Res. 1, 33-49 (1978)

Altieri, M.A., van Schoonhoven, A., Doll, J.D.: The ecological role of weeds in insect pest management systems: A review illustrated by bean (Phaseolus vulgaris) cropping systems. Proc. Nat. Acad. Sci. 23, 195-205 (1977)

Atsatt, P.R., O'Dowd, D.J.: Plant defense guilds. Science 193, $2429(1976)$

Bach, C.E.: Effects of plant density and diversity on the population dynamics of the striped cucumber beetle, Acalymma vittata (Fab.). PhD thesis. Ann Arbor, Michigan: University of Michigan 1979

Chambliss, O.L., Jones, C.M.: Cucurbitacins: specific insect attractants in Cucurbitaceae. Science 153, 1392-1393 (1966)

Cromartie. W.J.: The effect of stand size and vegetational background on the colonization of cruciferous plants by herbivorous insects. J. Appl. Ecol. 12, 517-533 (1975)

Cromartie, W.J.: The environmental control of insects using crop diversity. In: Pest Management C.R.C. Handbook Series in Agriculture (D. Pimentel, ed.), in press

DaCosta, C.P., Jones, C.M. : Cucumber beetle resistance and mite susceptibility controlled by the bitter gene in Cucumis sativus L. Science 172, 1145-1146 (1971 a)

DaCosta, C.P., Jones, C.M.: Resistance in cucumber, Cucumis sativus $\mathrm{L}$. to three species of cucumber beetles. Hortscience 6, 340-342 (1971 b)

Dempster, J.P.: Some effects of weed control on the numbers of the small cabbage white (Pieris rapae L.) on Brussel Sprouts. J. Appl. Ecol. 6, 339-345 (1969)

Dempster, J.P., Coaker, T.H.: Diversification of crop ecosystems as a means of controlling pests. In: Biology in Pest and Disease Control (D.P. Jones and M.E. Solomon, eds.), pp. 106-114. London: Blackwell Scientific Pub. 1974

Douwes, P.: Host-selection and host-finding in egg-laying female Cidaria albulata L. (Lepidoptera: Geometridae). Opusc. Entomol. 33, 233-279 (1968)

Flaherty, D.L. : Ecosystem trophic complexity and Willamette mite Eotetranychus willametei Ewing (Acarina: Tetranychidae) densities. Ecology 50, 911-916 (1969)

Haynes, R.L., Jones, C.M.: Wilting and damage to cucumber by spotted and striped cucumber beetles. Hortscience 10, 265-266 (1975)

Hill, R.E., Hixson, E., Muma, M.H.: Corn rootworm control tests with benzene hexachloride DDT, nitrogen fertilizers, and crop rotations. J. Econ. Ent. 41, 392-401 (1948)

Houser, J.S., Balduf, W.V.: The striped cucumber beetle. Bull. Ohio Agr. Exp. Sta. 388 (1925)

Howe, W.L., Sanborn, J.R., Rhodes, A.M.: Western corn rootworm adult and spotted cucumber beetle associations with Cucurbita and Cucurbitacins. Env. Ent. 5, 1043-1048 (1976)

Kennedy, J.S.: Mechanisms of host plant selection. Ann. appl. Biol. 56, 317-322 (1965)

Murdoch, W.M., Evans, F.C., Peterson, C.H.: Diversity and pattern in plants and insects. Ecology 53, 819-829 (1972)

Pimentel, D.: The influence of plant spatial patterns on insect populations. Ann. Ent. Soc. Am. 54, 61-69 (1961 a)

Pimentel, D.: Species diversity and insect population outbreaks. Ann. Ent. Soc. Am. 54, 76-86 (1961 b)

Pimentel, D.: The ecological basis of insect, pest, pathogen, and weed problems. In: Origins of Pest, Parasite, Disease, and Weed Problems (J.M. Cherett and G.R. Sagar, ed.), pp. 3-31. London: Blackwell Sci. Pub. 1977

Pollard, E. : Hedges VI. Habitat diversity and crop pests: A study 
of Brevicoryne brassicae and its syrphid predators. J. Appl. Ecol. 8, 751-780 (1971)

Price, P.W., Waldbauer, G.P.: Ecological aspects of pest management. In: Introduction to Insect Pest Management (R.L. Metcalf and W.H. Luckman, eds.), pp. 37-73. New York: John Wiley and Sons 1975

Root, R.B.: Organization of a plant-arthropod association in simple and diverse habitats: the fauna of collards (Brassica oleracea). Ecol. Monogr. 43, 95-124 (1973)

Root, R.B. : Someconsequences of ecosystem texture. In : Ecosystem Analysis and Prediction (S.A. Levin, ed.), pp. 83-97. Philadelphia: Soc. Ind. Appl. Math. 1975

Smith, E.F.: Bacteria in Relation to Plant Diseases, Vol. 2. Washington, D.C.: Carnegie Institute of Washington 1911

Smith, J.G.: Some effects of crop background on populations of aphids and their natural enemies on brussel sprouts. Ann. appl. Biol. 63, 326-330 (1969)
Smith, J.G.: Influence of crop background on aphids and other phytophagous insects on brussel sprouts. Ann. appl. Biol. 83, $1-13$ (1976a)

Smith, J.G.: Influence of crop background on natural enemies of aphids on brussel sprouts. Ann. appl. Biol. 83, 15-29 (1976 b)

Southwood, T.R.E., Way, M.J.: Ecological background to pest management. In: Concepts of Pest Management (R.L. Rabb and F.E. Guthrie, eds.), pp. 6-29. Raleigh, North Carolina: North Carolina State University Press 1970

Tahvanainen, J.O., Root, R.B.: The influence of vegetational diversity on the population ecology of a specialized herbivore, Phyllotreta cruciferae (Coleoptera: Chrysomelidae). Oecologa 10, 321-346 (1972)

van Emden, H.F., Williams, G.F.: Insect stability and diversity in agroecosystems. Ann. Rev. Ent. 19, 455-475 (1974)

Received September 1, 1979 